\section{TRANSFORMASI NILAI LOKAL YANG DIEKSPRESIKAN WAYANG TOPENG MALANG SEBAGAI \\ SUMBER PENDIDIKAN KARAKTER}

\section{Robby Hidajat}

Staf. Pengajar Jurusan Seni dan Desain Fakultas Sastra Universitas Negeri Malang (UM) E-mail: gantargumelar@gmail.com

\section{Abstrak}

Penelitian ini bertujuan menggali nilai-nilai lokal yang bersumber dari Wayang Topeng Malang (WTM). Pendekatan yang diterapkan adalah transformasi dengan teori fungsional-struktural. Tujuan penelitian ini dimaksudkan mencari relasional nilai-nilai yang diekspresikan WTM. Penggalian data dilakukan pada perkumpulan Wayang Topeng Asmarabangun di Dusun Kedungmangga, Kecamatan Pakesaji, Kabupaten Malang melalui pengamatan (observer partisipatoris) dan wawancara. Analisis penelitian ini menggunakan metode hermeneutik terhadap WTM. Hasil penelitian menunjukan signifikasi transformasi nilai-nilai lokal tentang pendidikan-estetik dan sosial-egaliter yang dapat digunakan sebagai sumber pendidikan karakter dalam membentuk sikap siswa sekolah.

Kata-kata kunci: wayang, topeng, pendidikan, karakter.

\section{TRANSFORMASI NILAI LOKAL YANG DIEKSPRESIKAN WAYANG TOPENG MALANG SEBAGAI SUMBER PENDIDIKAN KARAKTER}

\section{Abstract}

This study aims to explore the values sourced from Malang Mask Puppe (WTM). The approach adopted is the transformation of the functional-structura theory. The purpose of this study is seeking relational values in WTM. The data were taken from a WTM community named Asmarabangun in Kedungmangga Village, Pakesaji District, Malang Regency through observation (participatory observer) and interviews. The analysis of this study was conducted by using hermeneutic methods. The results showed the significant transformation of local values related to aesthetics education and social-egalitarian that can be used as an educational resource in shaping the character and attitudes of school students.

Key words: Puppet, Mask, Education, Character.

\section{PENDAHULUAN}

Wayang Topeng Malang (WTM) adalah seni pertunjukan yang menjadi transmisi dalam mempertemukan gagasan, tindakan, dan materi. Secara umum dapat dikenali melalui indikator dari tradisi lisan lakon Ramayana dan Mahabarata (Amir, 1997: 63). Dua lakon hasil alkulturasi budaya India itu ditemukan kecenderungan tokoh-tokoh protagonis dan antagonis bersifat hitam-putih, yaitu melihat presentasi tokoh hanya dua; alus (halus) dan gagah (kasar). Dua ini yang menentukan realitas dunia menjadi seolah-oleh 'hitam' dan 'putih.' Mentalitas Jawa yang bersifat hitam-putih itu adalah gaya pemikiran dan tema kultural Jawa (Mulder, 19-20). Mentalitasa itu merupakan dasar dari moral Jawa yang menempatkan kebaikan/kebenaran di atas kejahatan; suradira jayaningrat lebur dining pangastuti (kejahatan selalu dihancurkan oleh kebenaran) (Sesetya, 2007 : $80)$.

Tema kultural ini terjalin secara kontinuitas dalam tata nilai yang diturunkan dari generasi ke generasi, termasuk yang hidup dalam WTM. Hal itu ditemukan dalam pengumpulan data arkeologis dan antropologi dari abad VIIVIII di Jawa Timur (masa pemerintahan Gajahyana dan popularitas ajaran Agastiya) (Holt dalam Soedarsono, 2000: 76). Bahkan ditemukan kontinuitas nilai-nilai yang bersifat kelokalan pada lakon, gerak tari, musik (gamelan), dan pola penyajian. Transformasi nilai-nilai lokal yang diekspresikan melalui WTM hingga sekarang masih diyakini oleh masyarakat Dusun Kedungmangga, yaitu melalui transmisi suguh pundhen. Menurut Chattam Ar salah satu murid Karimoen; pundhen itu berasal dari kata pe-pundhen (nenek moyang) (Hasil wawancara pada 21 Mei 2012). Ritus pemohan restu pada nenek moyang itu dijumpai pada ritus manusuk sima (seremonial penetapan raja yang membebaskan wilayah dari segala kewajiban beban pajak) dan shraddha (ritual penyempurnaan awah setelah 12 tahun meninggalnya Sri Rajapatni, nenek raja Hayam Wuruk). Pada dua ritual itu mengetengahkan 'topeng' sebagai sajian estetik (Earl Drake, 2012: 158-159).

Suguh Pundhen merupakan Aktivitas ritual sosial, yaitu dimaksudkan sebagai bersih desa. Tujuannya adalah menggerakan emosi spiritual yang disebut wilujengan (selamatan). Penyelenggaraan ritual itu selenggarakan di pundhen desa dalam siklus waktu tahunan, yaitu jatuh pada bulan Ruwah yang jatuh pada hari Senin Legi. Secara transformatif ritual suguh pundhen itu berasal dari ritual nyadran (berkait dengan kata shraddha) ritus itu ditujukan untuk menyempurnakan roh.

Emosional spiritual yang kontinu dilakukan masyarakat Jawa terhadap nenek moyang adalah ekspresi moralitas yang disebut 'bakti', berikutnya diekspresikan dalam wujud sikap ngabekti. Tindakan emosi spiritual itu berakar dari bentuk tanggung jawab yang harus dipikul oleh anak laki-laki sulung sebagai 
wakil ibu dan keluarga (Zaehner, 1992 :147-154). Tanggung jawab itu mendudukan anak laki-laki sulung dari sebuah keluarga menjadi pemimpin upacara (darma yang dilakukan oleh Hayam Wuruk). Ketika orang tua meninggal dunia, bentuk bakti sebagai rasa syukur dan sikap hormat hormat itu harus terus dilanjutkan. Hal tersebut dilakukan karena rasa hormat tidak dapat dilakukan secara nyata, maka yang dapat dilakukan adalah simbolis ritus penghormatan pada roh leluhur (Durkheim, 2011 : 87). Nilai-nilai ini telah berakar dalam kehidupan masyarakat Jawa, khususnya masyarakat pemangku Wayang Topeng di Dusun Kedungmangga.

Keterkaitan antara ungkapan emosional spiritual bakti dan nenek moyang menjadi pola masyarakat di Malang (Jawa Timur) dalam ngalap berkah slamat. Oleh karena itu, topeng difungsikan berbagai aktivitas ritual pembebasan (tolak balak), seperti ritual inisiasi (khitanan, pernikahan), membayar nadhar/kaul (membayar hutang janji pada diri sendiri), dan pembebasan atas ancaman marabahaya yang disebut ruwatan (Dwiyanto \& Saksono, 2012: 92-98).

WTM terkait dengan ritual yang didasari dengan empati spiritual dari masyarakat pemangku WTM. Tindakan itu adalah refleksi transformatif tata nila dan etika budaya Jawa yang diekspresikan melalui vokalitas (suara), kinestetik (rasa gerak yang dihayati penari), dan wujud imitasi figur topeng sebagai pengganti wajah penari (empati terhadap bentuk).

Ekspresi estetik yang ditampilkan penari di atas pentas adalah manivestasi roh-roh nenek moyang bangsawan Majapahit; raja-raja dari masa kejayaan Kerajaan Singasari, Jenggala, Kediri, Ngurawan, dan Gegelang (Poerbotjaraka, 1968). Adanya persepsi itu, maka terjadi sebuah jalinan emosional historis. Fenomena ini merupakan pola sikap yang dapat membentuk menjadi pola pembentukan sikap nasionalisme; bangsa yang besar adalah bangsa yang dapat menghargai pahlawannya. Artinya, faktor-faktor historis langsung dapat dipelajari melalui empati emosional.

Selain itu, masyarakat pemangku WTM yang tumbuh di Dusun, Kedungmonggo meyakini nilai-nilai filosofis tentang kosmologi triloka (tiga dunia), kesetangkupan (dualitas) dan kemanunggalan. Semua itu terimplementasi pada pemahaman 'sih langgeng' (cinta abadi), yaitu kasih sayang Tuhan terhadap makhluknya. Spirit sih langgeng ini membangun spirit masyarakat mengekspresikan makna simbolis dalam wujud penghormatan leluhur yang disebut bakti (spiritual Hindhu), darma (spiritual Budhis), atau sedehak (spiritual Islam) (Hidajat, 2008: 63-64). Fenomena ini memberikan pemahaman, bahwa ad hubungan signifikan yang menjadikan manusia menjadi 'baik' jika mampu menumbuhkan rasa cinta. Wujud implementasinya adalah sikap berbakti pada orang tua, guru, dan Tuhan. Sikap itu merupakan perbuatan baik yang sangat mulia, bahkan menjadi bagian yang sangat mendasar dalam kehidupan, apabila tidak ada harta yang dapat disedekahkan.

Di dalam aktivitas ritual selalu ada relasional antara pemangku dengan aspek yang diyakini, dan juga aspek pengharapan yang dipanjatkan sebagai permohonan atau rasa syukur. Relasi yang mampu terus dibangun dan dijaga kontinuitas dalam bentuk usaha transformasi etika, moralitas dan struktur yang dalam perkembangan ruang dan waktu. Sesuatu ini sudah barang tentu ada koreksi dan koneksi, atau ada upaya untuk membangun kohesi sosial, yaitu konstruksi sosial melalui aktivitas ritual menurut konsep Durkheim. Religi merupakan sesuatu yang tidak dapat dielakkan dalam kehidupan satu masyarakat. Dalam masyarakat sederhana religi merupakan sumber utama kohensi sosial, yaitu melalui emosional (Muhni, 1994:16).

Mekanisme sosial itu berdampak pada terbentuknya konstruksi mentalitas pada pembelajar seni tari. Berbagai fenomena transfomatif dilakukan seniman Wayang Topeng dari waktu ke waktu. Seni pertunjukan WTM mengalami dinamika pasang surut, perubahan bentuk dan gaya adalah aspek eksternal. Akan tetapi, faktor internal masih memberikan sumbangan terhadap tata nilai yang bersifat lokal, khas sebagai mentalitas budaya Jawa.

Hipotesa penelitian yang berjudul Transformasi Nilai Lokal yang Diekspresikan Wayang Topeng Malang Sebagai Sumber Pendidikan Karakter adalah: Ada pengaruh signifikan antara religi tradisional dan seni pertunjukan Wayang Topeng yang menjadi transmisi aktualisasi nilai-nilai lokal, tingkah laku, dan material melalui artistik-simbolis seni pertunjukan Wayang Topeng terhadap siswa sekolah. Alasan mengarahkan pada jenjang sekolah diasumsikan, bahwa masa pertumbuhan anak masih dalam tahap (1) belajar bergaul dengan teman sebaya (sosialisasi diri), (2) mempelajari peran sosial seseorang laki-laki dan perempuan (menghayati peran tokoh dalam seni pertunjukan), dan (3) belajar mengambil bagian secara bertanggungjawab seagai anggota masyarakat (mengekspresikan emosional sosial pada orang tua, keluarga, dan masyarakat, terkati dengan penumbuhan sikap rasa kasih sayang) (Havighursf, 1984:21-22).

\section{METODE}

Penelitian ini dikembangkan dari penelitian desertasi yang berjudul: Wayang Topeng Malang: Transformasi Artistik-Simbolis Ritual Pertunjukan ke Seni Pertunjukan di Kabupaten Malang Jawa Timur. Tujuan penelitian ini didasarkan pada aspek fungsional-struktural yang mengikuti mazhab Talcott Parson (1902-1979), yaitu memandang perkembangan budaya ditentukan oleh aspek fungsi dan struktur yang saling terkait (Royce, 2007 : 81-82). Cakupan teorì adalah (1) Masyarakat merupakan kesatuan utuh dalam kegiatan interaksi antarindividu (prinsip holistik); (2) Interaksi dapat berlangsung timbal-balik atau 
searah, yang menggunakan komunikasi simbolis; (3) Masyarakat bersifat dinamis dalam kesatuan sistemik; dan (4) Perubahan berlangsung secara gradual dalam proses transformatif dan bersifast adaptif (Alimandan, 2002: 21). Adapun teori analis menggunakan teori estetik (Victor Turner), Semiotik (Roland Barthes), dan seni pertunjukan (Soedarsono) yang disebut etnokoreologi. Data yang digunakan pada penelitian ini adalah keterangan lisan, tingkah laku atau tindakan, catatan atau dokumen, dan berita media. Alat pengambilan data disamping alat tulis, ala elektronik dan digital audio-video adalah peneliti itu sendiri. Kehadiran peneliti di lapangan memiliki makna strategis dalam rangka membangun empati, yang khas dalam pola analisis Verstehen (Usman \&Akbar, 2001: 81; Mulder, 1996: 5).

\section{HASILPENELITIAN}

Hasil penelitian ini menunjukan adanya transformasi tentang 1) kedudukan dalang dan 2) kedudukan tokoh sentral WTM, yang dapat dikemukakan sebagai berikut.

\section{Nilai Moral pada Tokoh Sentra}

Tokoh-tokoh sentral pada WTM dalam berbagai jenis lakon yang disajikan terdiri: Gunungsari dan Panji Asmarabangun, sebagai tokoh putra alu (halus) yang memiliki watak baik. Klana Sewandana sebagai tokoh kasar (gagah) yang memiliki watak tidak bertanggung jawab, dan Dewi Sekartaji yang menjadi topik dalam semua repertoar lakon WTM. Hasil analisis ditemukan korelas sebagai bentuk transformasi diakronisnya sebagai berikut.

Tabel 1. Transformasi nilai-nilai spiritual, dan realitas pada WTM

\begin{tabular}{|l|l|l|l|}
\hline \multicolumn{1}{|c|}{$\begin{array}{c}\text { Tokoh repertor } \\
\text { WTM }\end{array}$} & $\begin{array}{c}\text { Makna dan posisi } \\
\text { tokoh }\end{array}$ & \multicolumn{1}{|c|}{$\begin{array}{c}\text { Transformasi } \\
\text { spiritual }\end{array}$} & $\begin{array}{c}\text { Realitas } \\
\text { masyarakat desa }\end{array}$ \\
\hline Klana Sewandana & $\begin{array}{l}\text { pengganggu } \\
\text { ketentraman sosial }\end{array}$ & Siwa (urip) & Roh pengganggu \\
\hline Panji Asmarabangun & $\begin{array}{l}\text { Penjaga } \\
\text { keseimbangan sosial }\end{array}$ & $\begin{array}{l}\text { Wisnu (sing } \\
\text { ngurupi) }\end{array}$ & $\begin{array}{l}\text { Pamong desa } \\
\text { (kamitowo) }\end{array}$ \\
\hline Sekartaji & Simbul kesuburan & $\begin{array}{l}\text { Dewi Sri (Dewi } \\
\text { kesuburan) }\end{array}$ & $\begin{array}{l}\text { Desa dan } \\
\text { kehidupan } \\
\text { masyarakat }\end{array}$ \\
\hline Gunungsari & $\begin{array}{l}\text { Mengembalikan } \\
\text { posisi } \\
\text { keseimbangan alam }\end{array}$ & $\begin{array}{l}\text { Brahma (sing } \\
\text { gawe urip) }\end{array}$ & Dhayang \\
\hline
\end{tabular}

Transformasi tokoh Wayang Topeng dapat disimulasikan dalam tokoh pada realitas kehidupan masyarakat desa. Siwa adalah merepresentasikan Klana; dalam bahasa Jawa Kuno berarti Raksasa. Klana Sewandana selalu mengancam stabilitas dunia (jagad), sehingga berbagai hajat hidup masyarakat menjadi kacau, rusak, dan tidak lagi mampu mencapai tata tentrem karta raharja. Dhayang adalah manifestasi Brahma, yaitu sing gawe urip. Posisi itu ditempati oleh Gunungsari. Dewi Kesuburan reflesi dari biyung tani. Dewi Kesuburan seringkali mendapat ancaman dari Klana. Tugas Klana adalah mengganggu stabilitas alam raya agar mampu melakukan proses dinamisator:

Klana Sewandana juga hadir dalam manifestasi Bethara Kala yang menjadi tema sentra penyajian pada ritual Riwatan Sukerto. Relasi transformatifnya dapat ditemukan seperti pada tabel di bawah ini.

Tabel 2. Transformasi tokoh Wayang Topeng, Wayang Purwa, lembaga adat,dan keyakinan kuno

\begin{tabular}{|l|l|l|l|}
\hline \multicolumn{1}{|c|}{$\begin{array}{c}\text { Tokoh Wayang } \\
\text { Topeng }\end{array}$} & \multicolumn{1}{|c|}{$\begin{array}{c}\text { Tokoh Wayang } \\
\text { Purwa }\end{array}$} & $\begin{array}{c}\text { Tokoh Lembaga } \\
\text { adat }\end{array}$ & Keyakinan kuno \\
\hline Panji Asmarabangun & Batara Guru & Kamituwo & $\begin{array}{l}\text { Roh pelindung } \\
\text { desa }\end{array}$ \\
\hline Klana Sewandna & Batara Kala & Pundhen & Dhanyang \\
\hline Gunungsari & Wisnu & Dalang & Saman (dukun) \\
\hline
\end{tabular}

Masyarakat menyelenggarakan ritual ruwatan disebakan takut atas kondisi sukerto, yaitu ancaman marabahaya atas asal kelahiran atau prilakunya yang melanggar tabu (Pamungkas, 2002 : 28-52). Ritual ruwatan Wayang Topeng pada umumnya dilaksanakan oleh orang-orang yang tinggal di sekitar kaki Gunung Tengger; Malang sebelah timur, seperti Dusun Gubukelakah, Ngadireso, Wangkal, Jambe ijo dan sekitarnya (Soleh, wawancara, 2 Agustus 2011). Masyarakat di desa-desa di wilayah Tengger yang beragama Hindhu Jawa menganggap tabu menyelenggarakan ruwatan dengan media Wayang Kulit, karena lakon wayang purwa pada umumnya memvisualisasikan dan membicarakan para dewa, khususnya Batara Brahma. Di daerah (Bromo \& Tengger) tabu memainkan prilaku para dewa. Oleh karena itu, pilihannya jatuh pada Wayang Topeng. Akan tetapi, dalang yang memainkan harus mampu sebagai dalang pengruwatan. Dalang ini merupakan dalang keturunan, yang paling mujarab japa mantranya. Dalang tersebut adalah keturunan ketujuh atau setidaknya keturunan ketiga.

Dalang-dalang pangruwatan merupakan trasformator intelektual yang memahamkan semesta kosmor Jawa, yaitu sebuah sistem analogi antara arah kiblat, anasir zat inti bumi yang secara mikro ada dalam diri manusia, aspek simbolisasi warna, hari pasaran (pancawara), nepu hari, unsur kadewatan, hingga terkait dengan karakteristik watak tokoh sentral pada WTM. 
Tabel 3. Relasi saptawara dan tokoh WTM

\begin{tabular}{|l|l|l|l|c|l|l|l|}
\hline $\begin{array}{c}\text { Arah } \\
\text { kiblat }\end{array}$ & Anasir & Warna & $\begin{array}{c}\text { Panca } \\
\text { wara }\end{array}$ & $\begin{array}{c}\text { Naptu } \\
\text { hari }\end{array}$ & $\begin{array}{c}\text { Watak } \\
\text { dewa }\end{array}$ & Tokoh WTM & Sifat \\
\hline Timur & Air & Putih & Legi & 5 & Sri & Sekartaji & $\begin{array}{l}\text { Lapang } \\
\text { dada, iklas }\end{array}$ \\
\hline Selasan & Api & Merah & Pahing & 9 & Kala & Klana & $\begin{array}{l}\text { Tamak, } \\
\text { rakus, } \\
\text { jahat }\end{array}$ \\
\hline Barat & Angin & Kuning & Pon & 7 & Brahma & Ragel kuning & $\begin{array}{l}\text { Sombong, } \\
\text { menyombo } \\
\text { ngkan diri }\end{array}$ \\
\hline Utara & Tengah & Hitam & Wage & 4 & Wisnu & Gunungsari & $\begin{array}{l}\text { Teguh hati, } \\
\text { kaku }\end{array}$ \\
\hline Tengah & Rasa & $\begin{array}{l}\text { Manca } \\
\text { warna }\end{array}$ & $\begin{array}{l}\text { Kli- } \\
\text { won }\end{array}$ & 8 & Siwa & $\begin{array}{l}\text { Panji } \\
\text { Asmarabangun }\end{array}$ & $\begin{array}{l}\text { Pandai } \\
\text { bicara, } \\
\text { supel }\end{array}$ \\
\hline
\end{tabular}

\section{Relasi Nilai Tokoh Sentral}

Panji Asmarabangun, yang menjadi tokoh utama (protagonis) dalam pertunjukan wayang topeng, memiliki kedudukan inti sebagai sumber utama pengembangan tema dan permasalahan. Dengan demikian, keberadaannya lebih bersifat produktif dalam menjalin kaitan-kaitan dengan tokoh yang lain, baik yang protagonis atau antagonis.

\section{a. Panji Asmarabangun dan Dewi Candrakirana}

Kedudukan Panji Asmarabangun dan Dewi Candrakirana bersifat simbolik pertemuan bapa (ayah) dan Biyung (ibu). Pertemuan ini ditujukan untuk menghadirkan roh Ilafi (roh idlafi) atau Mul Himah. Maka hakikat ayah dan ibu adalah sangat luhur dan diluhurkan. Oleh karena itu, mereka memiliki hak untuk dihormati.

Pemahaman sosial religius Jawa diistilahkan: Loro-loroninge a-Tunggal (dua menjadi satu). Pemahaman ini ada dalam konsep kekuasaan Jawa yang disebut dengan istilah Dewa Raja, yaitu pengertian raja sebagai legitimasi dan sekaligus manifestasi dari Dewa. Menyimak hal tersebut, maka Panji Asmarabangun yang dikemudian hari akan mendapatkan legitimasi untuk menggantikan ayahandanya, Panji Lembu Amilihur yang dipersepsi sebaga Samiaji atau Darmakesuma, raja dari kerajaan Amarta. Seorang raja yang bijaksana dan memiliki budi yang luhur.

Panji membutuhkan pengalaman, yaitu selalu ditakdirkan untuk berkelana menjadi rakyat jelata, untuk mencari istrinya yang hilang/menghilang dari istana. Ini memiliki aspek sosio-politis, yaitu seorang raja Jawa tidak lagi dipersepsi sebagai manifestasi dewa, tetapi juga merupakan manifestasi rakyat, sehingga Panji diperjalankan untuk dapat mendengar dan melihat kondisi rakyatnya. Pada dalang WTM di Malang mengartikan 'lelana ing laladhan sepi,' (berkelana dalam suasana yang sunyi, yaitu selepas tengah malam dalam mengontemplasi diri, merenungi barbagai hal yang telah diperbuat atau yang dialami dalam waktu sehari).

Memperhatikan hal ini adalah satu bentuk pemikiran yang mulai bergeser dari sikap raja-raja Jawa, maka sastra panji ini lebih terkenal sebagai sastra rakyat ketimbang sastra istana. Hal ini disebabkan pola cerita yang dibangun lebih berorentasi pada rakyat, dan bersifat realistik terhadap kehidupan manusia. Nilainilai yang diekspresikan adalah memahami secara mendalam tentang hidup dan kehidupan rakyat.

Hubungan ayah dan ibu ini memang dibutuhkan lambang-lambang untuk memberikan pamor yang spektakuler, yaitu dengan membangun simbilisme dalam tokoh Panji Asmarabangun dan Galuh Candrakirana, yaitu ditunjukan sebagai sebuah siklus pergantian siang dan malam, yaitu Panji sebagai Matahari dan Candrakirana sebagai Bulan Purnama. Perwujudan simbolis yang umum dijumpai pada benda pemujaan masa Jawa Timur adalah lambang kesuburan, dalam wujud lingga-yoni, atau lumpang-alu, cowek-muntu (ulek-ulek).

\section{b. Panji Asmarabangun dan Gunungsari}

Kedudukan Panji Asmarabangun dan Gunungsari merupakan pertemuan antara laki-laki dan laki-laki dengan hakikat yang berbeda. Hal ini seperti pertemuan antara Harjuna dan Semar. Semar adalah pengejawantahan dari Dewa Manikmaya, sehingga Semar bersifat maya atau semu, Budha Manang Munung atau Jejanggan Asmara Santa. Semar ditunjukan dari perwujudan sebagai manusia yang sempurna, yaitu tidak memiliki jenis kelamin yang jelas (laki-laki atau wanita). Ini memiliki kesamaan konsep dengan Gunungsari, yang disamakan dengan tokoh Samba putra Krisna. Samba sebagai sosok yang memiliki penampilan kewanitaan (feminin) merupakan kesatuan hubungan yang abadi tanpa ada perbedaan, sehingga tidak terjadi pertentangan atau konflik dari keduannya. Akibatnya, kehadirannya merupakan kondosi Ramawijaya dan Lesemana, yaitu loro-loroning a-tunggal yang bersifat positif (tanpa konflik). Dalam wujud perilaku sosial dapat diperhatikan pada aktivitas suguh pundhen. Masyarakat desa menyatukan dirinya dengan roh nenek moyang, penyatuan diri dalam ritual selamatan atau Wilujengan. Aktivitas ritual tradisional merupakan upaya menjalin kemanunggalan, nyawiji, atau manjing. Kondisi ini dimaksudkan menjalin solidaritas egaliter. Penyamaan kedudukan individu dengan Gusti dan rakyatnya. Pola prilaku ini yang dimaknai sebagai solidaritas egaliter. Pemahaman yang bersifat filosofis ini mampu direduksi, bahwa hidup itu harus mampu belajar 
hidup secara sosial yang bersifat kesetaraan. Sikap ini yang dapat dikonstruksi oleh guru sebagai pembentukan sikap seperti sesetaraan gender, kesejajaran, dan mampu berempati terhadap orang lain.

\section{c. Dewi Candrkirana dan Klana Sewandana.}

Hubungan Dewi Candrakirana dan Klana Sewandana juga tampak ditumbuhkan dari epos Ramayana, yaitu Dewi Candrakirana yang tampak dibangun dari kondisi sebagai Sinta, titisan dari Betari Sri (saktinya Wisnu).Aspek ini mendukung konsep tentang maesan (keyakinan kurban penyempurnaan roh nenek moyang) yang diartikan sebagai perwujudan Yani (lambang Siwa) dan tanah sebagai Lingga (Sri, lambang kesuburan). Sementara pangejawantahan Panji Asmarabangun sebagai Arjuna atau Sri Rama dan Dewi Candrakirana sebagai Sumbadra atau Sinta, hal ini menunjukan pengukuhan tema trasformatif yang menunjukan hubungan sikap kesetiaan, loyalitas.

Kedudukan tokoh sentral memiliki kaitan yang erat, yaitu menduduki rentang ruang dan waktu, bahkan menempati posisi dalam konsepsi tata nilai Sehingga keberadaan empat tokoh sentral dalam kosmologi Jawa adalah dua bagian yang tidak dapat dipisahkan satu sama lain, yaitu nilai positif dan nila negatif yang dibawa oleh manusia dari lahir hingga meninggal dunia. Sejak usia dini, manusia dilatih dan dibiasakan menghadapi problematika kehidupan Kontradiktif dalam kehidupan itu adalah proses untuk mendewasakan pemahaman terhadap realitas yang bersifat material maupun yang bersifat kerohanian. Ini menjadi makna dari topeng dan penari. Sebuah relasi antara material simbolis yang digerakkan penari. Akan tetapi, ekspresi artistik penari itu adalah penyatuan antara keduanya. Fenomena ini yang disebut ngejawantah (be-ing). Semua pengetahuan yang dipelajari harus dapat diimplementasikan melalui sikap dan perbuatan. Oleh karena itu, nilai-nilai ngejewantah, artinya menjadi wujud sangat dibutuhkan pada perkembangan mentalitas dan sikap anak usia sekolah.

\section{KESIMPULAN DANSARAN}

\section{Kesimpulan}

Hasil kajian transformasi nilai-nilai lokal WTM adalah sebuah pembentukan kebudayaan atas proses koneksitas antara waktu (diakronis) dan dalam masa tertentu (sinkronis) hubungan fungsional-struktural masyarakat pendukungnya, yaitu kontinuitas nilai-nilai potensial dan asasi yang terus berproses penyerapan dan sekaligus pelepasan dalam proses pembentukan struktur sosial masyarakat. Dengan demikian dapat disimpulkan sebagai berikut.

a. WTM merupakan transmisi nilai-nilai lokal yang mengikat hubungan sosia antar individu dalam bermasyarakat (tindakan sosial), berdasarkan berbagai potensi berkesenian dalam dinamika kebudayaan masyarakat di Malang.
Akibatnya terjadi dinamika nilai-nilai kultural yang berdampak pada aspek kearifan lokal tentang pendewasaan mentalitas estetik dalam pertumbuhan siswa usia sekolah (utamanya siswa SD kelas rendah).

b. WTM merupakan proses pelembagaan komunikasi simbolik yang membentuk kesadaran baru masyarakat pengalaman hidup. Ritus-ritus yang terkait dengan seni pertunjukan Wayang Topeng mampu membangun aspek solidaritas egaliter dalam pembentukan mentalitas dan kesadaran penghayatan tentang aspek makrokosmos (jagad gede) dan mikrokosmos (jagad cilik), penyatuan diri dan pembentukan empati sosial, sehingga anak tidak hanya sebagai objek, tetapi mempunyai kemampuan dialogis memahami pikiran orang lain.

c. WTM merupakan potensi yang membuat masyarakat mengubah persepsinya, dari pemahaman mitologis ke realitas. Perkembangan zaman menempatkan pola seni pertunjukan Wayang Topeng yang mampu mengkonstruksi sikap dan tata nilai dalam memahami realitas sosial, termasuk dalam memandang dunia yang memiliki dinamika di berbagai segmen kehidupan. Melalui pemahaman tersebut, diharapkan para guru sekolah mampu menerjemahkannya dalam bentuk penyiasatan belajar. Dengan cara demikian, siswa diharapkan mampu memahami realitas, apakah benda tertentu termasuk mistis, magis, mekanik, humanis, atau merupakan realitas yang secara bertubi-tubu muncul dalam wacana media.

\section{Saran}

WTM merupakan seni pertunjukan yang memiliki keterkaitan emosional dengan masyarakat pendukungnya. Hal ini dibuktikan dengan adanya keterkaitan yang signifikan terhadap proses sosial dan mentalitas masyarakat dari waktu ke waktu. Oleh karena itu, disarankan beberapa hal berdasarkan temuan di atas.

a WTM memungkinkan untuk dipertahankan sebagai sumber kajian pengetahuan tentang tata nilai sosial dan estetik bagi siswa sekolah

b. WTM dapat digunakan sebagai sumber referensi bagi guru seni tari untuk menggali berbagai kemungkinan nilai-nilai kearifan lokal sebagai aspek pendorong untuk mengembangkan materi belajar dan strategi belajar di sekolah.

c. WTM dapat digunakan sebagai materi bahan ajar pada jenjang sekolah melalui pembelajaran keterampilan. Dari pada itu, pada guru dapat melakukan transformasi pembelajaran karakter dari tokoh-tokoh yang ada pada repertoar pertunjukannya. Dengan demikian, akan terjadi transformasi sikap, dan empati positif bagi siswa sekolah. 


\section{DAFTAR PUSTAKA}

Amir, Hazim. 1997. Nilai-Nilai dalam Wayang. Jakarta: Pustaka Sinar Harapan.

Durkheim, Emile. The Elementary Forms of The Religious Life. Terj. Inyaiak Ridwan Muzir. Yogyakarta: IRCiSoD.

Dwiyanto, Djoko \& Suksono, Gatut. 2012. Faham Keselamatan dalam Budaya Jawa. Yogyakarta: Ampera Utama.

EarlDrake, 2012. Gayatri Rajapatni: perempuan di Balik Kejayaan Majapahit. Yogyakarta: Ombak.

Hidajat, Robby. 2008. Wayang Topeng Malang. Malang: Gantargumelar.

Holt, Claire. Melacak jejak Perkembangan Seni di Indonesia. Terj. Soedarsono. 2000. Bandung: Masyarakat Seni Pertunjukan Indonesia.

Muhni, Djuretna A., (1994), Moral dan Religi: Menurut Emile Durkheim \& Heri Bergson, Kanisius: Yogyakarta.

Mulder, Niels. 1983. Kebatinan dan Hidup Sehari-Hari Orang Jawa: Kelangsungan dan Perubahan Kulturil. Jakarta: Gramedia.

Mulder, Nils. 2011 (cetakan5). Mistisisme Jawa Ideologi di Indonesia. Yogyakarta: LKiS

Rocyce, Annya Peterson. 2007. Antropologi Tari. Terj. Wiaryanto, F.X. Bandung: sunan Ambu.

Saksono, Gatot \& Dwiyanto, Djoko. 2012. Faham Keselamatan dalam Budaya Jawa. Yogyakarta: Ampera Utama.

Soedarsono \& Narawati, Tati. 2011. Dramatari di Indonesia, Kontinuitas dan Perubahan. Yogyakarta: Gadjah Mada University Universitas Press.

Soedarsono. 1997. Wayang Topeng: Drama Tari Ritual Kenegaraan di Kraton Yogyakarta. Yogyakarta: Gadjah Mada Universitas Press.

Zaehner, Robert C. 1992. Kebijaksanaan dari Timur. Terj. Sudiarja. Jakarta: Gramedia. 